\title{
POPULATION DYNAMICS OF APHIS CRACCIVORA KOCH, LIRIOMYZA TRIFOLII (BURGESS) AND THE ASSOCIATED PREDATORS ON FABA BEAN PLANTS
}

\author{
M.R. EL-Aassar ${ }^{(1)}$, Samia M. Abozaid(1), A.A. Mourad ${ }^{(2)}$ and E.A.M. Mousa ${ }^{(1)}$ \\ (1) Vegetable Pests Department, Plant Protection Research Institute ARC Dokki, Giza, Egypt. \\ (2) Harmful Animals Research Dept., Plant Protection Research Institute ARC Dokki, Giza, \\ Egypt.
}

Received: Mar. 23, 2017

Accepted: Apr. 23, 2017

\begin{abstract}
Two field experiments were carried out in Qaliobia and Kafr EL-Sheikh governorates during 2014/2015 season to study the population dynamics of Aphis craccivora Koch , Liriomyza trifolii (Burgess) infesting faba bean plants and the role of the associated predators on the population changes in the tested pests. Broad bean plants were cultivated, weekly leaf samples were collected and examined in the laboratory by a dissecting stereomicroscope as well as the numbers of the three predators: Coccinella undecimpunctata L., Chrysopela carnea (Stephs), and Orius albidipennis (Reut.) were recorded. The obtained results showed that the overall relative abundance of Aphis craccivora and Liriomyza trifolii were 26 and $74 \%$, respectively at Kafr EL-Sheikh governorate, and were 50\%, 34 \%, 18\% for C. undecimpunctata, C. carnea, O. albidipennis, respectively. As for Qaliobia governorate the overall relative density of Aphis craccivora and Liriomyza trifolii were $48.5 \%$ and $51.5 \%$, respectively, and were $35.5 \%, 37 \%, 30 \%$ for C. undecimpunctata, C. carnea, O. albidipennis, respectively. Results also indicated that the three predators reduced the population numbers of A.craccivora and L. trifolii by $36 \%$ and $12 \%$, respectively. The obtained results showed that C. undecimpunctata was the most active predator against both tested pests .
\end{abstract}

Key words: Aphid, leaf miner, predators, Vicia faba, explained variance (E.V\%).

\section{INTRODUCTION}

Broad Bean, Vicia faba L. is one of the most important leguminous crops that provide a major source of protein for human in Egypt (Rizk, 2011). This crop is highly susceptible to the infestation with cowpea aphid, Aphis craccivora Koch, which considered the main pest of broad bean under Egyptian climatic conditions (Mathew et al, 1971; Saleh et al, 1972; Vercambre, 1980; EL Dafrawi et al., 2000; and Ragab et al., 2002), and Liriomyza trifolii Burgess (Mohamed and SIman, 2001). The two previous mentioned serious pests are affecting in the quantitative and qualitative yield of crop causing economic damage (Lima, 1970; Weigan and Bishara, 1991).

Biological control is a main tool of integrated control programs, since it is concerned with biotic agents including parasitoids, predators and/or pathogens (Stary, 1970). Vanderycken et al. in Belgium (2011) recorded the occurrence of aphid natural enemies (Hoverflies, coccinellids and lacewings in several agro-ecosystem, corn, wheat, potato, broad bean).

The present study aims to determine the population of Aphis craccivora and Liriomyza trifolii, which attack broad bean crop in two governorates; Kafr EL-Sheikh and Qaliobia, as well as the population of three predators : Coccinella undecimpunctata, Chrysopela carnea (Steph.) and Orius albidipennis (Reu.). Which found to be associated with the two pests and their role in decreasing the population density of studied pests.

\section{MATERIALS AND METHODS}

Field experiments were conducted in a 
private farm in two governorates, Kafr ElShiekh and Qaliobia, during 2014/2015 season. About one feddan $4200 \mathrm{~m}^{2}$ in each area was divided into four plots cultivated with broad bean, Vicia faba Giza 3 variety, in the first of November of 2014 to estimate the population of the most destructive pests found to affect the yield of the crop besides the most dominant predators found to be associated with the pests. Experimental plots received the usual recommended agricultural practices and were kept without any chemical control through the growing seasons.

Apical leaves of 10 plants were randomly collected for each replicate (20 leaves) to be examined the number of Aphis craccivora.

Also, samples of 20 leaves from two levels of the plant (middle and lower) parts were weekly randomly collected and put in a paper bags to be examined in the laboratory and the leaves were examined with stereomicroscope to record the number of mines of leafminer, Liriomyza trifolii.

Direct count using manual lens $(5 \mathrm{x})$ for associated predators (C. undecimpunctata, C. carnea, and $O$. albidipennis) were carried out and 10 plants were randomly chosen for further examination.

\section{The percentage of relative density was calculated as follows:}

Relative density $=$ No. of individual of species / No. of all individuals of all species x100

Statistical analysis, correlation partial regression test for the tested pests with their predators were estimated to find out the relation between its associated predators and the percentage of pests population (Snedcor and Cochran, 1967).

\section{RESULTS AND DISCUSSION: \\ I. Kafr El-Sheikh: \\ 1- Aphis craccivora population:}

The obtained results illustrated in Figure (1) show the population fluctuation of Aphis craccivora during the period from
December, 2014 to March , 2015 at Kafr ElSheikh region. As cleared from the figure, the population density started with average number of 94 individuals/10 apical leaves recording the first peak of abundance during the $3^{\text {rd }}$ week of December, 2014. While, the $2^{\text {nd }}$ peak occurred on the $3^{\text {rd }}$ week of January, 2015 recording 154 individual/10 apical leaves. After that, the population decreased gradually and disappear completely during February and March, 2015.

\section{2- Liriomyza trifolii population:}

As shown in Figure (1) the population density of Liriomyza trifolii recorded four peaks of abundance. The $1^{\text {st }}$ two peaks were recorded during the $1^{\text {st }}$ and $4^{\text {th }}$ week of January, 2015 (91 and 110 individuals/ 20 leaves, respectively). The $3^{\text {rd }}$ peak was observed during the $2^{\text {nd }}$ week of February, 2015 (40 individuals/20 leaves). While, the $4^{\text {th }}$ peak occurred in the $2^{\text {nd }}$ week of March, 2015 (304 individuals/20 leaves). Interestingly, the highest peak was observed during the $2^{\text {nd }}$ week of February.

\section{3- Coccinella undecimpunctata:}

The number of the predator began to appear on $3^{\text {rd }}$ week of December, 2014 recording 11 individuals/10 plants, these numbers gradually increased giving its highest numbers of this predator synchronized with the highest peak of $L$. trifolii 58 individuals/10 plants in the $2^{\text {nd }}$ week of March, 2015.

\section{4- Chrysopela carnea:}

Regarding to the number of counted predator on broad bean associated with the mentioned two pests (Figure 1), it is obvious that predators number ranged from 4 to 27 individuals and the considerable numbers of this predator appeared during winter months (December, January, and February).

\section{5- Orius albidipennis:}

The number of $O$. albidipennis was slightly low ranging from 0 to 13 individuals giving its highest number in the $4^{\text {th }}$ week of January, 2015. 


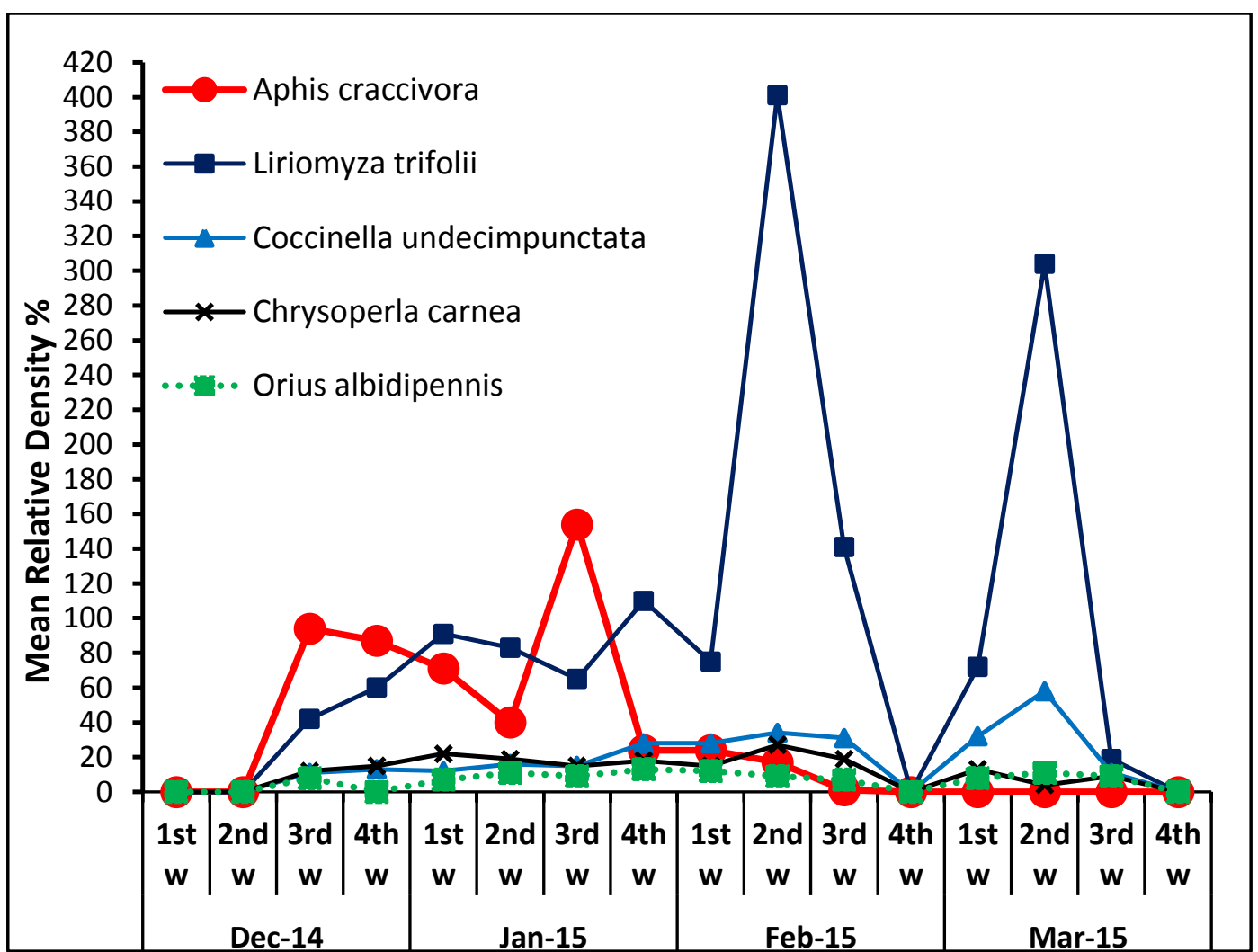

Relative density \% was counted from the total insect pests only.

Figure (1): Weekly population density of two pests and three associated predators in Kafr El shiek governorate at 2014/2015 season

\section{Relation between the two pests and associated predators:}

Data in Table (1) show the simple correlation ( $r$ ) and partial regression (b) values of $A$. craccivora and the population of C. undecimpunctata in Kafr EL-Sheikh governorate, togather with the levels of probability. The obtained results indicated that there is a negative significant correlation between the population of the pest and predator $(r=-0.59)$ depending on the $(b)$ values 0.34 , this means that the increase of the predator may decrease the population of the pest. The simple correlation ( $r$ ) values of $C$. carnea and $O$. albidipennis and the pest population recorded insignificant correlation (0.10 and -0.36).

The overall explained variance (E.V. \%) of the three combined predators was $37 \%$, this is meaning that combined effect of the three associated predators was more effective on the $A$. craccivora population on the broad bean plants, Vicia faba during 2014-2015 season. Similarly, the effect of $C$. undecimpunctata showed negative significant correlation with population $(r=$ 0.73 ). The E.V. of the three predators recorded $75 \%$, therefore, this agent played a crucial role in minimizing the $L$. trifolii population more than other factors.

\section{Qaliobia governorate: \\ 1-Aphis craccivora population:}

Data illustrated in Figure (2) show the number of $A$. craccivora found to be attacking broad bean crop in Qaliobia governorate during the season of 2014/2015 besides the number of the three predators found to be associated with it. The pest began to appear during the $2^{\text {nd }}$ week of December recording 62 individuals/10 apical leaves, recording four peaks, the highest peak of 90 individuals occupied in the $3^{\text {rd }}$ week of January. 


\section{EL-Aassar, et al.,}

\section{2- Liriomyza trifolii population:}

The Legume leafminer, $L$. trifolii, recorded three peaks, the highest one was 93 mines occurred during the $4^{\text {th }}$ week of December. The number of the pest ranged from 18-93 mines, as for the three predators found to be associated with the tested two pests, $C$. undecimpunctata recorded number ranged between 4 to 24 individuals. While, C. carnea and $\mathrm{O}$. albidipennis recorded numbers ranged 7 to 27 and 6 to 22 individuals, respectively.

As shown in Figures (1 and 2), the relative abundance of the two tested pests and the three predators in two governorates of study revealed that leafminer was more abundant $(74 \%)$ than aphid (26\%) in Kafr ElShiekh governorate. In addition, $C$. undecimpunctata recorded $50 \%$ followed by C. carnea (32\%) and O. albidipennis (18\%). On the other hand, in Qaliobia region, the pests recorded slight differences in the population density (aphid, 48.5 and leafminer, $51.5 \%$ ). While, the predators recorded $33.5 \%, 37 \%$, and $30 \%$ for $C$. undecimpunctata, C. carnea, and $\mathrm{O}$. albidipennis, respectively.

\section{Relation between the two pests and associated predators:}

The data in Table (2) show that the relationship between tested predators; $C$. undecimpunctata, $C$. carnea and $O$. albidipennis and the infestation of aphid, $A$. craccivora, was a negative relationship. This means that the increase of predators decreased the levels of aphid infestations on broad bean, $V$. faba. The highest correlation coefficient was recorded in case of predator, C. undecimpunctata by -0.51 .

The explained variance between these natural enemies and the infestation of $A$. craccivora ranged between $2 \%$ and $26 \%$. The highest explained variance was $26 \%$ in case of $C$. undecimpunctata suggesting that this predator more active against aphid a long with slight efficacy on leafminer than other predators in this study.

On the other hand, the overall explained variance of the three tested predators (E.V. $\%)$ with the population fluctuation of $A$. craccivora was $36 \%$ on broad bean in Qaliobia governorate (Table 2).

As for leaf miner, L. trifolii, data in (Table 2) cleared that the correlation coefficient was positive relationship between the three tested predators and the population fluctuation of the pest except with $O$. albidipennis, which recorded a negative insignificant relationship being - 0.26 . However, a slight explained variance was recorded with $L$. trifolii. The explained variance was ranged from $1 \%$ to $7 \%$. The overall explained variance between the population densities of $L$. trifolii and the three previous natural enemies was $12 \%$.

Table (1): The simple correlation(r), partial regression (b), and explained variance (E.V.\%) of the relation between two pests attacking broad bean and three associated predators in Kafr El-Sheikh governorate in 2014/2015 season.

\begin{tabular}{|l|l|c|c|c|c|c|}
\hline Pest & Predators & r & b & E.V\% & F. & E.V\% \\
\hline \multirow{4}{*}{$\begin{array}{l}\text { Aphis } \\
\text { craccivora }\end{array}$} & C. undecimpunctata & $-0.59^{*}$ & 0.34 & $34 \%$ & 5.22 & \\
\cline { 2 - 6 } & C. carnea & 0.10 & 0.01 & $1 \%$ & 0.111 & \multirow{2}{*}{$37 \%$} \\
\cline { 2 - 6 } & O. albidipennis & -0.36 & 0.13 & $13 \%$ & 1.46 & \\
\hline \multirow{4}{*}{$\begin{array}{l}\text { Liriomyza } \\
\text { trifolii }\end{array}$} & C. undecimpunctata & $0.73^{*}$ & 0.53 & $0.53 \%$ & 11.208 & \multirow{2}{*}{$75 \%$} \\
\cline { 2 - 6 } & C.carnea & 0.26 & 0.07 & $7 \%$ & 0.733 & \\
\cline { 2 - 6 } & O.albidipennis & 0.19 & 0.04 & $4 \%$ & 0.388 & \\
\hline
\end{tabular}




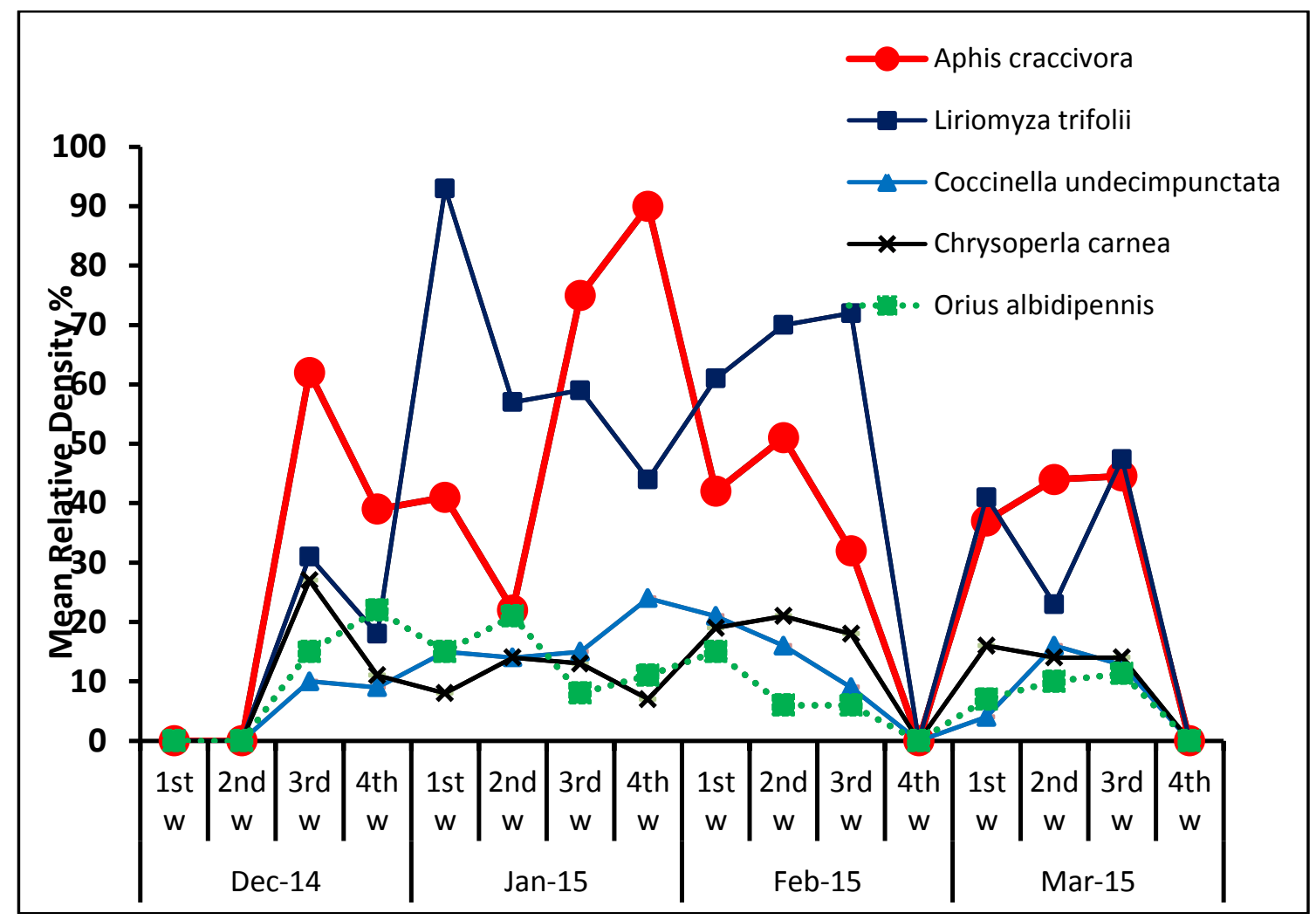

Relative density \% was counted from the total insect pests only.

Figure (2): Weekly population density of two pests and three associated predators in Qaliobia governorate at 2014/2015 season

Table (2): The simple correlation (r), partial regression (b), and explained variance (E.V.\%) of the relation between two pests attacking broad bean and three associated predators in Qaliobia governorate in 2014/2015 season:

\begin{tabular}{|l|l|c|c|c|c|c|}
\hline Pest & Predators & $\mathbf{r}$ & $\mathbf{b}$ & E.V\% & F. & \multirow{2}{*}{ E.V\% } \\
\hline \multirow{3}{*}{$\begin{array}{l}\text { Aphis } \\
\text { craccivora }\end{array}$} & C.undecimpunctata & $-0.51^{*}$ & 0.26 & $26 \%$ & 3.16 & \\
\cline { 2 - 6 } & C.carnea & -0.15 & 0.02 & $2 \%$ & 0.20 & \multirow{2}{*}{$36 \%$} \\
\cline { 2 - 6 } & O.albidipennis & -0.29 & 0.09 & $9 \%$ & 0.85 & \\
\hline \multirow{3}{*}{$\begin{array}{l}\text { Liriomyza } \\
\text { trifolii }\end{array}$} & C.undecimpunctata & 0.21 & 0.04 & $4 \%$ & 0.41 & \\
\cline { 2 - 6 } & C.carnea & 0.10 & 0.01 & $1 \%$ & 0.09 & \multirow{2}{*}{$12 \%$} \\
\cline { 2 - 6 } & O.albidipennis & -0.26 & 0.07 & $7 \%$ & 0.67 & \\
\hline
\end{tabular}


From the previous data, it can be concluded that $C$. undecimpunctata gave a considerable and significant reduction for both $A$. craccivora and L. trifolii in Kafr ELSheikh and Qaliobia regions, and the combined of the three tested predators recording $37 \%$ and $75 \%$ for A. craccivora and L. trifolii in Kafr EL-Sheikh, Where these predators for the three tested predators in Qaliobia governorate recorded $36 \%$ and $12 \%$ for the two pests, respectively.

Thus, it is obvious from the foregoing data that $C$. undecimpunctata had strong effect in minimizing $A$. craccivora but the other two tested predators recorded slight effects for the $L$. trifolii in the two governorates, like these results must be in mined to explain the integrated control program for these pests.

\section{REFERENCES}

EL-Defrawi, G.M., A.K. Eman, I.A. Marzouk, and L. Rizkalla (2000). Population dynamics and seasonal distribution of Aphis craccivora koch and associated natural enemies in relation to virus disease incidence in faba bean fields. Egyptian Journal of Agricultural Research, 78(2): 627-641.

Lima, C. P.F. De. (1970). Liriomyza trifolii (Diptera: Agromyzidae), an important new leaf miner pest in Kenya. Kenya entomologist' s News letter. (10): 8.

Mathew, K.P., M. J. Thomas and M.R.G.K. Nair (1971). population fluctuations of the pea aphid in relation to climate and predators. Agricultural Research Journal of Kerala. 9 (1): 23-26.

Mohamed, A. M. and F. A. A. SIman (2001). Susceptibility of some broad bean varieties to natural infestation with Aphis craccivora Koch and Liriomyza trifolii (Burgess) at Upper Egypt. Assiut J. Agric. Sci., 32(1): 167-173.
Ragab, M. E., A. M. Abou EL-Naga and A. A. Saleh (2002). Ecological studies on certain aphid parasitoids, especially those of Aphis craccivora Koch. J. Agric. Sci. Mansoura Univ., 27(4): 2611-2620.

Rizk, Amany M. (2011). Effect of stripmanagement on the population of the Aphid, Aphis craccivora Koch and its associated predators by intercropping Faba bean, Vicia faba L. with Coriander, Coriandrum sativum L. Egypt. J. Biol Cont., 2(1), 81-87.

Saleh, M. R. A., M. H. Hassanein and A. H. EL-Sebae (1972). Population dynamics of Aphis craccivora Koch on broad bean and cowpea in Upper Egypt. Bull. Soc. Ent. Egypt, 65: 135-138. (C.F. R. A. E. A) 62 Abst., (No. 4140).

Snedcor, G. W. and W. G. Cochran (1967). Statistical Methods, sixth edition, lowa state college press, Ames. lowa, USA.

Stary, P. (1970). Biology of Aphid parasites (Hymenoptera: Aphidiidae) with respect to integrated control. Series Entomol, Vol, 6 Dr. W. Junk, The Hague, 643 pp.

Vandereycken, A., D. Durieux, E. Joie and F. J. Verheggen (2011). Is the multicolored Asian ladybird the most abundant aphid ophagous species in agroecosystem les cochenilles: ravageur principal ousecondaire. Geme conference Internationalesur les Ravageurs en Agriculture SupAgro, Amontpellier, France, 25-27 October 2011.

Vercambre, B. (1980). Studies conducted in Reunionlsl and on the broad-bean leafminer, Liriomyza trifolii Burgess. Revue Agricole et Sucriere de L'lle Maurice. 59(3): 147-157.

Weigan. D. S. and S. I. Bishara (1991). Status of insect pests of faba bean in the Mediterranean region and methods of control. In: cubero J. I. (ed.). 
ديناميكية تعداد حشرتى من البقوليات وصانعة انفاق اوراق الفول والمفترسات المصاحبه لهما على نبات الفول

مسعود رشاد الأعصر (1)، سامية منذر أبوزيد(1)،عبدالرعوف احمد مراد (2)، عصام موسى (1)

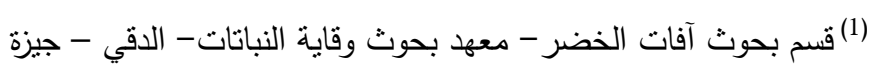

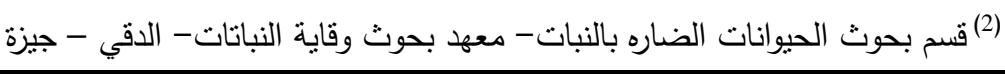

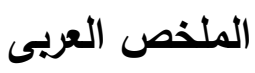

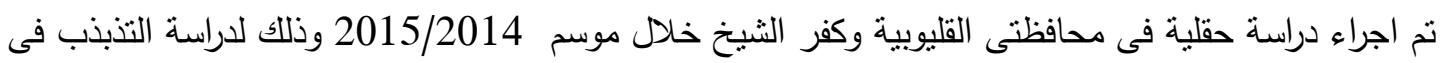

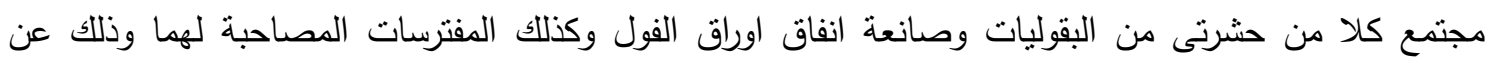

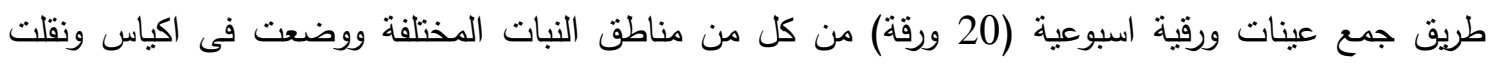

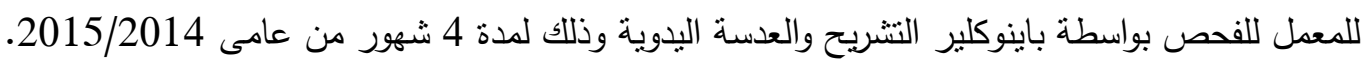

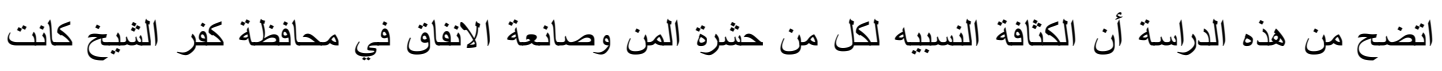

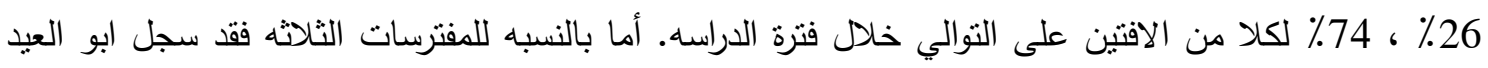

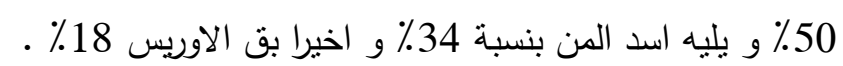

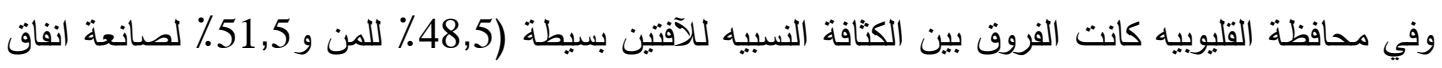
اوراق الفول ) خلال فترة الدراسة .

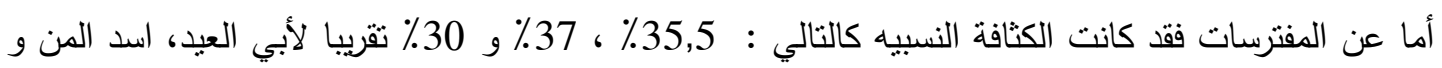

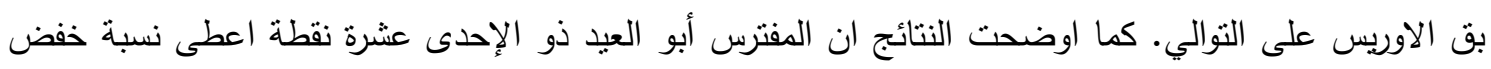

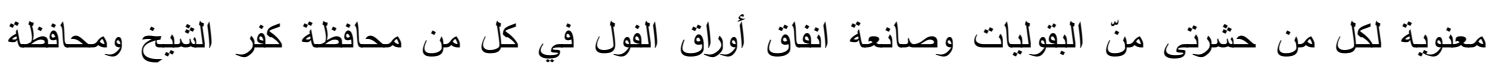
القليوبية. كذلك يتضح من الدراسة تأثير الثلاث مفترسات (أبو العيد ذو الإحدى عشرة نقطة - أسد المنّ - بقة الأوريس)

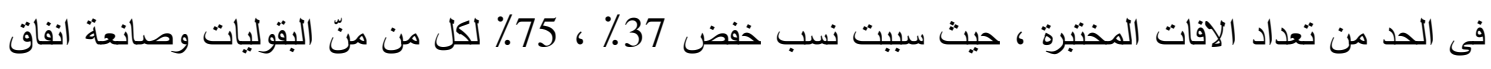

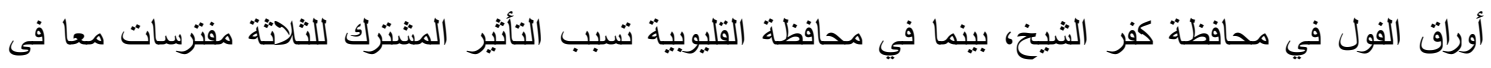

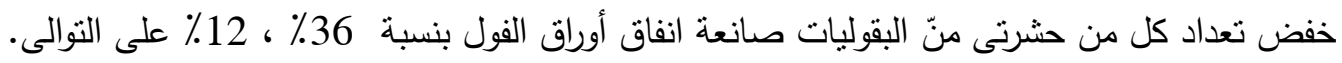

